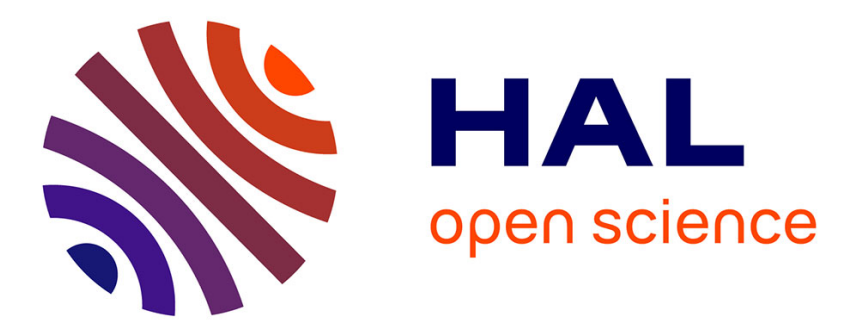

\title{
HIGHLY COERCIVE FILMS IN THE SYSTEM $\gamma$ Fe2O3 - Fe3O4, OBTAINED BY A NEW PYROLYSIS TECHNIC
}

\author{
M. Langlet, M. Labeau, J. Joubert
}

\section{- To cite this version:}

M. Langlet, M. Labeau, J. Joubert. HIGHLY COERCIVE FILMS IN THE SYSTEM $\gamma$ Fe2O3 Fe3O4, OBTAINED BY A NEW PYROLYSIS TECHNIC. Journal de Physique Colloques, 1985, 46 (C6), pp.C6-41-C6-44. 10.1051/jphyscol:1985606 . jpa-00224844

HAL Id: jpa-00224844 https://hal.science/jpa-00224844

Submitted on 1 Jan 1985

HAL is a multi-disciplinary open access archive for the deposit and dissemination of scientific research documents, whether they are published or not. The documents may come from teaching and research institutions in France or abroad, or from public or private research centers.
L'archive ouverte pluridisciplinaire HAL, est destinée au dépôt et à la diffusion de documents scientifiques de niveau recherche, publiés ou non, émanant des établissements d'enseignement et de recherche français ou étrangers, des laboratoires publics ou privés. 

B.P. 46, 38402 Saint Martin d'Hères, France

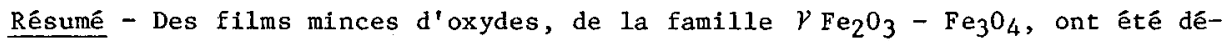
posés sur des substrats de verre par pyrolyse d'un aérosol formé par ultrasons. La composition, la morphologie et les propriétés magnétiques de ces films dẹpendent fortement de la température et de l'atmosphère de dépôt. En ajustiat ces paramètres, on obtient des films dont l'aimantation est voisine de celle des matériaux massifs. Un bon contrôle de la composition des phases obtenues permet d'aboutir à une coercivité de $1^{\prime}$ ordre de 1000 le.

\begin{abstract}
Pyrolysis of an ultrasonic generated aerosol has been used for gro-

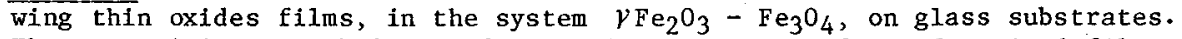
The composition, morphology and magnetic properties of the deposited films are observed to be strongly influenced by the temperature and atmospher of deposition. Adjusting this two parameters results in films with magnetization close to the value of bulk materials. Good control of the films composition results in a coercivity up to $1000 \mathrm{Oe}$.
\end{abstract}

\title{
I - INTRODUCTION
}

Iron oxides films in the systen $\gamma \mathrm{Fe}_{2} \mathrm{O}_{3}-\mathrm{Fe}_{3} \mathrm{O}_{4}$ are particulary attractive for application in high density magnetic recording /1,2/. In our laboratory we have prepared such films by a new spray pyrolysis method named Pyrosol process $/ 3 /$ and based on the pyrolysis of an aerosol produced by ultrasonic spraying. This technic leads to better films quality than the classical methods of CVD or pneumatic spraying and requires simple and economical equipment. We used it for growing thin films of magnetite $\mathrm{Fe}_{3} \mathrm{O}_{4}, \mathcal{Y F e}_{2} \mathrm{O}_{3}$ oxide and $\mathrm{\gamma Fe}_{2} \mathrm{O}_{3}-\mathrm{Fe}_{3} \mathrm{O}_{4}$ solid solutions. The obtained films presented magnetic properties which are believed to be suitable for high bit density magnetic recording applications.

\section{II - EXPERIMENTAL}

The experimental system have been presented elsewhere (LANGLET and al. submitted to IEEE, 1985). The liquid source to be sprayed was a solution of iron acetylacetonate dissolved in butano1 and contained in a glass vessel whose bottom was fitted with a piezoelectric transducer. Excitation of the piezoelectric ceramic at a frequency near $750 \mathrm{khz}$ resulted in the aerosol formation at the surface of the 1iquide. This aerosol was transported by a carrier gas near the heated glass substrate on which pyrolysis occured. The carrier gas consisted in a mixture of oxygen and argon. The general pyrolysis reaction occuring at the substrate surface can be written as follows :

$$
\text { Fe }\left(\mathrm{C}_{5} \mathrm{H}_{7} \mathrm{O}_{2}\right)_{3} \frac{\mathrm{O}_{2}}{\mathrm{Ar}}-(1-\mathrm{x}) \mathrm{Fe}_{3} \mathrm{O}_{4} \cdot \mathrm{x} \mathrm{Fe} / 3 \mathrm{O}_{4}+\text { décomposition products }
$$

resulting in the formation of a spinel $\mathcal{V F e}_{2} \mathrm{O}_{3}$ - Fej $\mathrm{O}_{4}$ solid soltion. $\mathrm{X}$ ray diffraction confirmed the polycristalline cubic spinel structure of the deposited films. The composition of the solid solution was controlled by the oxygen proportion in the gas flow and by the substrate temperature. Magnetite $\mathrm{Fe}_{3} \mathrm{O}_{4}$ films were obtained under pure argon at a temperature between 420 and $540^{\circ} \mathrm{C} . \quad \gamma_{\mathrm{Fe}_{2} \mathrm{O}_{3}} \mathrm{films}$ were obtained between 
420 and $450^{\circ} \mathrm{C}$ in a gas mixture of $\mathrm{Ar}$ and $\mathrm{O}_{2}$ in the ratio $0_{2} / \mathrm{Ar} \approx 10^{-2}$ to $10^{-3}$. $\mathrm{VFe}_{2} \mathrm{O}_{3}$ films were also obtained by post oxidation of magnetite films. Annealing magnetite films in air at $250^{\circ} \mathrm{C}$ resulted in a solid solution (1-x) $\mathrm{Fe}_{3} \mathrm{O}_{4}-\mathrm{x} \mathrm{Feg}_{3} \mathrm{O}_{4}$ whose oxidation degree $x$ depended on the oxidation time. After complete oxidation, $\mathrm{PFe}_{2} \mathrm{O}_{3}$ phase $(\mathrm{x}=1)$ was obtained. All the obtained polycristalline films had a thickness of 2000 to $8000 \AA$, with a good adherence to the substrates. The cristallites.size varied from 200 to about 1000 \& depending on the experimental conditions of deposition.

\section{III - RESULTS}

Lattices parameters of the deposited phases were measured using a unit cell refinment program. Fig. I shows the substrate temperature dependance of the lattice constant for the as deposited magnetite films (curve a) and for the same films after complete oxidation at $250^{\circ} \mathrm{C}$ (curve b). These figures show that values of the lattice constants close to bulk values of $\mathrm{Fe}_{3} \mathrm{O}_{4}$ and $\gamma \mathrm{Fe}_{2} \mathrm{O}_{3}$ phases are nearly obtained for a substrate temperature $T_{S}$ between 480 and $520^{\circ} \mathrm{C}$. For higher temperature the lattice parameters of the as deposited films and of the oxidized films fall well below the corresponding bulk values. We think that induced stress present in the films could be responsable for this diminution. Such a stress appears in the films after deposition, during cooling of the substrate from $\mathrm{T}_{\mathrm{s}}$ temperature to room temperature. It is due to the mismatch between the thermal expansion coefficients of the films and of the substrate. This stress distorts the lattice before and after oxidation treatment leading in each case to a diminution of the lattice parameters. The lattice distortion is particularly important at temperatures above $T_{S}=520^{\circ} \mathrm{C}$ because of a brutal increase of the expansion coefficient of the substrate at these temperatures. At substrate temperature lower than $480^{\circ} \mathrm{C}$ the oxidation kinetic during deposition is slowed down and smal1 quantities of hydrogen or other gas compounds ( $\mathrm{CO}$ or $\left.\mathrm{CO}_{2}\right)$ can be present in the films. This leads to abnormal values of the lattice parameters. Experiments of gas exodiffusion are under investigation to confirm this hypothesis.

Magnetization and coercive force have been measured after application of a $15 \mathrm{kOe}$ magnetic field perpendicularly to the films. There was no evidence of thickness influence on $M$ and $H_{c}$ values. Influence of the substrate temperature $T_{s}$ on magnetization and coercivity for magnetite films is showed on fig. 2. As both cristallite size and magnetic properties strongly increase when $T_{S}$ increases we think that at low temperature magnetic properties are probably more and more affected by the presence of superparamagnetism. This phenomena occurs when the size of the grains is smaller than a critical value of about $300 \AA$. The saturation magnetization of bulk magnetite is nearly reached for films deposited at $520^{\circ} \mathrm{C}$. Under these conditions a 400 oe coervice force is measured. Such a coercivity cannot be attributed to cristalline anisotropy because values of $\mathrm{H}_{c}$ observed on spherical particles of $\mathrm{Fe}_{3} \mathrm{O}_{4}$ are generally not higher than 150 0e. Coercivity is not caused either by shape anisotropy as our films are composed by grains somewhat spherical. Thus we believe that the observed anisotropy must be induced by stress developping between film and substrate during cooling, as mentioned above. When $\mathrm{T}_{s}$ increases the resulting stress at room temperature increases leading to a regular increase of $\mathrm{H}_{\mathrm{c}}$. At $540^{\circ} \mathrm{C}$ adherence of the films decreases because of the brutal increase in the expansion coefficient of the substrate at this temperature and then induced anisotropy decreases leading to a weaker value of $\mathrm{H}_{\mathrm{C}}$. Coercive force of magnetite films deposited at $520^{\circ} \mathrm{C}$ and then partially oxidized in air at $250^{\circ} \mathrm{C}$ is reported in $\mathrm{fig} .3$ as a function of the lattice constant. The cell parameter is strongly dependant on the oxidation degree of the obtained phase and varies from $a=8.396 \AA$ for magnetite to $a=8.339 \AA$ for oxidized ferric oxide $\mathrm{VFe}_{2} \mathrm{O}_{3}$. During oxidation the saturation magnetization value decrases regularly down to about $350-400 \mathrm{emu} / \mathrm{cc}$, a value close to that of bulk $\gamma_{\mathrm{Fe}} \mathrm{O}_{3}$. In addition slow oxidation of these magnetite films during a few hours at $250^{\circ} \mathrm{C}$ gives rise to an inportant increase of the coercive force that reaches values as high as 1000 oe and then decreases again when oxidation process is prolongated. Other investigators /4/ have already mentioned such a phenomena on oxidized magnetite films and explained it by a vacancy ordering in the obtained phase leading to an induced uniaxial anisotropy. We believe that stress present in the film can also participate to the anisotropy and explain such a variation in $\mathrm{H}_{c}$ value. So the nature of the substrate that is determinant of the stress present in the films can appear as a critical parameter to 
obtain highly coercive films by Pyrosol process. Other investigations will be made to allow a better comprehension of the observed magnetic properties.

IV - CONCLUSION

Pyroso1 process appears clearly to be a competitive and simple deposition method for growing magnetic iron oxides films with good homogeneity and adherence. Good control of the substrates temperature and of the oxidation degree of the deposited phases results in solid solution $\mathrm{Fe}_{3} \mathrm{O}_{4}-\mathrm{VFe}_{2} \mathrm{O}_{3}$ thin films with about $400 \mathrm{emu} / \mathrm{cc}$ in $\mathrm{M}_{\mathrm{s}}$ and 1000 oe in $\mathrm{H}_{c}$. Such properties are believed to be very suitable in high bit density magnetic recording applications

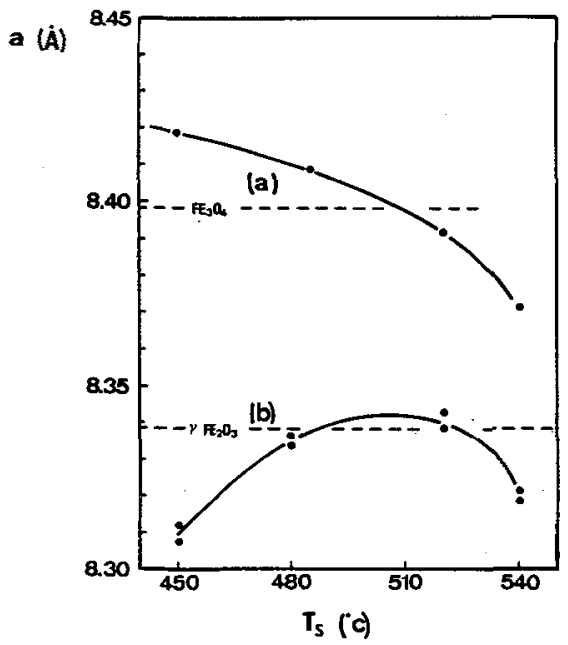

Fig. 1 - Influence of the substrate temperature on the lattice constant

(a) for films deposited in argon

(b) for the same films completely oxidized by annealing in air at $250^{\circ} \mathrm{C}$. Lattice parameters of bulk $\mathrm{Fe}_{3} \mathrm{O}_{4}$ and $\mathrm{V} \mathrm{Fe}_{2} \mathrm{O}_{3}$ are represented by dotted lines.

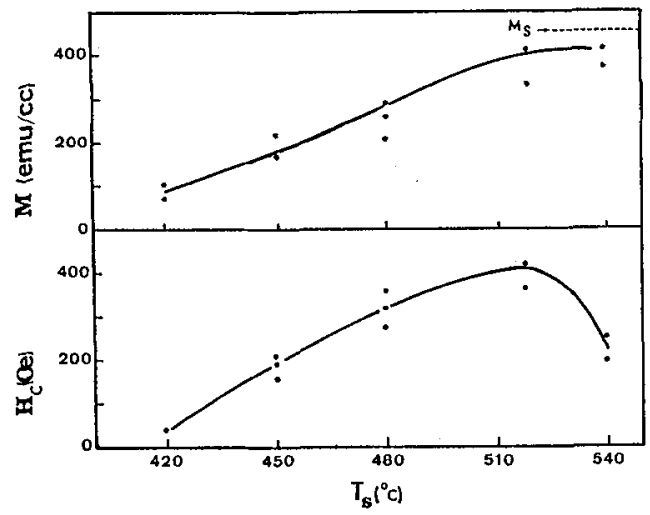

Fig. 2 - Magnetization at $15 \mathrm{k0e}$ and Coercivity vs substrate temperature for magnetite films. Saturation magnetization of bulk magnetite is represented by a dotted line. 


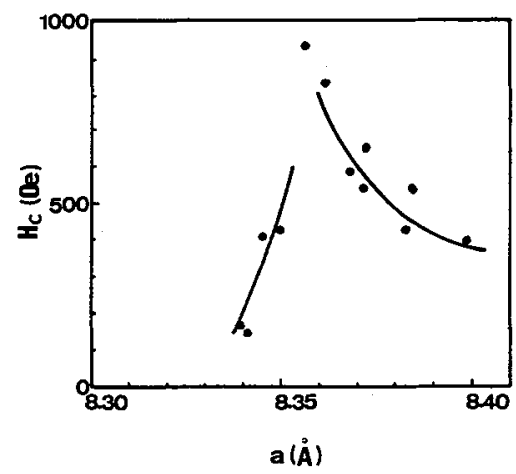

Fig. 3 - Coercive force vs lattice parameter for magnetite films deposited in argon at $520^{\circ} \mathrm{C}$ and subsequently oxidized in air at $250^{\circ} \mathrm{C}$ during various periods of time.

\section{REFERENCES}

/1/ S. Hattori, Y. Ishii, M. Shinohara and T. Nakagawa, IEEE Trans. Magnetics MAG 15, $\mathrm{n}^{\circ}$ 6, p $1549,1979$.

/2/ A. Terada, 0 . Ishii and $\mathrm{K}$. Kobayashi, IEEE Trans. Magnetics MAG-19, $\mathrm{n}^{\circ} 1, \mathrm{p} 12$, 1983

/3/ J. Spitz, J.C. Viguie, French Pat. 2, 110, 622 .

/4/ Y. Bando, A. Mishima, T. Shigematsu, S. Horii and T. Takada, Ferrites, Proc. Int'1 Conf., Japan, P 602, 1980. 